\title{
Review
}

\section{Autoantibody profile in juvenile chronic arthritis}

\author{
ALISON M LEAK \\ From the Clinical Research Centre, Watford Road, Harrow, Middlesex
}

SUMmaRY Patients with juvenile chronic arthritis (JCA) may be subdivided into a minority, who carry IgM rheumatoid factor and have erosive polyarthritis resembling adult rheumatoid $\vec{\sim}$ arthritis, and the majority $(90 \%)$, who are seronegative by conventional means. Between 30 and $\infty$

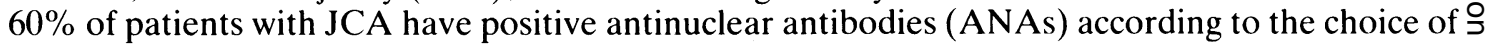
substrate for indirect immunofluorescence. The importance of ANAs is the frequent development of associated asymptomatic chronic iridocyclitis, which may impair vision causing worse handicap than the arthritis, which remains predominantly pauciarticular in two thirds of these $\frac{\widehat{O}}{\mathcal{S}}$ young children. ANA positive patients rarely possess antibodies to deoxyribonucleic acid (DNA) $\vec{\bullet}$ or extractable nuclear antigens (ENA), and current studies suggest that several different nuclear $\infty_{\infty}^{\infty}$ antigens, including histones, may be involved.

Key words: antinuclear antibodies, rheumatoid factors, indirect immunofluorescence, extract- $-\frac{\sum^{\supset}}{D}$ able nuclear antigens.

Juvenile chronic arthritis (JCA) encompasses a heterogeneous group of disorders whose clinical subdivisions have been supported by immunogenetic studies. ${ }^{12}$ Among numerous immunological abnormalities detected in JCA only antinuclear antibodies (ANAs) and IgM rheumatoid factor (RF) are currently thought to be useful in patient classification and management. ${ }^{3}$

About $10 \%$ of children with JCA have a seropositive arthritis resembling adult rheumatoid arthritis, ${ }^{4}$ but most never develop IgM RF measured by conventional Rose-Waaler techniques. ${ }^{5}$ Of those with seronegative disease, $20-30 \%$ have a systemic onset, and the remainder have either a pauciarticular or polyarticular arthritis. ${ }^{6}$

Children with seronegative polyarthritis may be ANA positive, but ANAs are most often found in children with late onset seropositive polyarthritis or in early onset pauciarticular arthritis, particularly when complicated by chronic iridocylitis. ${ }^{7}$ The specificity of the ANAs is unknown, and serum samples from these patients do not react with any of

Accepted for publication 9 September 1987.

Correspondence to Dr Alison M Leak, Clinical Research Centre. Division of Rheumatology, Watford Road. Harrow, Middlesex HAl 3UJ. the well characterised nuclear antigens identified in $\overline{\widehat{a}}$ adult autoimmune diseases.

Patients with systemic JCA rarely possess autoantibodies and their presence implies a different diagnosis, for example rash, fever, and arthritis with high titre ANAs suggests systemic lupus erythematosus or with low titre ANAs or RF suggests an infectious aetiology.

\section{The importance of methodology}

In discussing fluorescent ANA studies and interpreting low titre positive results the nature of the antigen preparation used and the sensitivity of each system is important. ${ }^{8}$ Wiik reported that most serumo samples from healthy adults and children were $\tilde{O}$ positive for at least one class of ANA, usually $\operatorname{IgM}, \mathbb{\omega}$ when tested undiluted in a highly sensitive assay, ${ }^{9} \mathrm{O}$ but other studies have only identified low titre $\operatorname{IgG}_{0}$ ANAs in $2 \%$ of normal children. ${ }^{10} 11$

A survey of 138 ANA positive children among? 1442 paediatric immunology/rheumatology outpatients found that a positive IgG ANA test at ao을 titre of at least $1 / 20$ was associated with definite or $\overparen{\mathbb{Q}}$ suspected autoimmune or rheumatic disease in $118 \overrightarrow{\mathrm{D}}$ and a further nine had $\operatorname{IgA}$ deficiency, ${ }^{12}$ which is associated with an increased incidence of rheumatic 
disease in children. ${ }^{13}$ Ten of the remaining 11 ANA positive patients had various infections, which may cause a temporary low titre positive ANA test, ${ }^{15}$ and one had leukaemia. ${ }^{12}$

In the detection of fluorescent ANAs more sensitive substrates such as $\mathrm{HEp}_{2}$ cells lead to decreased specificity, with $6-9 \%$ of healthy children having low titre ANAs $(1 / 20-1 / 40) .{ }^{16} 17$ Similarly, newer methods of detecting IgM RF, for example enzyme linked immunosorbent assays (ELISA), lead to a loss of specificity for erosive adult type polyarthritis unless low titre positive results are ignored. ${ }^{17}$

\section{Antinuclear antibodies}

Of all patients with JCA, 30-40\% are found to have positive ANAs of $\mathrm{IgG}$ class at a dilution of $1 / 40$ using rat or mouse tissue substrate. ${ }^{7} 1819$ With $\mathrm{HEp}_{2}$ cell immunofluorescence $5(--70 \%$ are positive, ${ }^{2} 17$ and in pauciarthritis associated with chronic iridocyclitis $88-100 \%$ are ANA positive. 71620 This disease pattern appears to be confined to the young age group ${ }^{21}$ and is associated with the HLA antigens A2, DR5, and DRw8. ${ }^{22}{ }^{23}$

Although less than $20 \%$ of patients with seronegative JCA will develop chronic anterior uveitis, ${ }^{2+26}$ with positive ANAs this increases to over $50 \%$. As the uveitis is asymptomatic but leads to severe loss of vision in more than $20 \%$ of affected eyes ${ }^{27-29}$ regular slit lamp examination is important. Identification of IgG ANAs in the aqueous humour of children with uveitis associated with JCA, at times in the absence of serum ANAs, suggests local synthesis. ${ }^{30}$ A role for soluble retinal antigen in the pathogenesis of uveitis has been suggested, ${ }^{31}$ and the histopathology and immunology of the eye in JCA have recently been reviewed. ${ }^{32}$

Serum ANAs may be positive either before or after the uveitis is discovered. ANA titres vary considerably during the course of disease, showing only weak associations with the activity of uveitis but stronger correlation with the activity of arthritis. ${ }^{33}$ In a study of 94 children with ANA positive seronegative JCA, patients with arthritis which remained persistently pauciarticular often had ANA titres of 1/640 early in the course of disease, but the ANA titre often became negative as the arthritis became inactive. Other children have persistent positive titres (1/80 to $1 / 160)$ associated with arthritis extending to a polyarticular pattern, unresponsive to long acting drugs. The joints of these children may remain active for as many as 10 or more years with considerable destruction and deformity; this pattern of severe extending arthritis is also seen in children who are ANA negative.

\section{Rheumatoid factors}

Seropositive polyarthritis accounts for $10 \%$ of JCA and patients are usually girls aged $10-16$ who have a nodular erosive arthritis associated with IgM RF, HLA-DR4, and which is indistinguishable from adult RA. ${ }^{+34}$ Mean levels of IgM antiglobulins detected by immunosorbent assay in patients with JCA are not usually raised above control values ${ }^{35}$ except in children positive by latex fixation, ${ }^{5}$ but Haynes et al have detected low titre IgM RF by ELISA in $35 \%$ of patients with JCA including all types of onset. ${ }^{17}$ Indirect immunofluorescence can detect IgM anti-IgG antibodies only in the adult type of JCA and not in seronegative arthritis, but these have also been found in juvenile onset connective tissue disorders. ${ }^{36}$

In contrast, IgG anti-IgG antibodies can be detected by indirect immunofluorescence in $88 \%$ of patients with JCA under the age of 16 and in children with other disorders, ${ }^{36}$ and by immunosorbent assay in all subclasses of $\mathrm{JCA}^{5},{ }^{57}$ where latex positive patients have the highest levels. ${ }^{5}$ Variable results have been reported in controls. ${ }^{5}{ }^{37}$ When a solid phase radioimmunoassay specifically measuring IgG RF was used, however, no subgroup of patients with JCA had values significantly different from those of controls and levels did not correlate with age, disease duration, or erythrocyte sedimentation rate.$^{35} \mathrm{IgA}$ antigammaglobulins have also been identified in $\mathrm{JCA}^{36}$ and, like IgG antiglobulins, have been associated with active disease, ${ }^{5}$ though their diagnostic value is doubtful. Certain $\mathrm{RF}$ in adult RA may cross react with nuclear antigens, ${ }^{38}$ and further studies of IgG RF found in JCA may be of interest.

Hidden 19S IgM rheumatoid factors are infrequently reported in JCA but have been detected in up to $68 \%$ of patients with JCA, though not in healthy children. ${ }^{39}$ They are found in all types of JCA, where they are associated with active disease. ${ }^{40}$ Wernick et al were unable to detect hidden RF in a small number of children, ${ }^{35}$ however, and Balogh et al found them in eight of 46 patients with JCA but also in $40 \%$ of controls. ${ }^{41}$

Thus IgM RF by latex fixation/Rose-Waaler is important as a screening test for seropositive polyarthritis with a poor prognosis, ${ }^{44}$ but other methods or assays of IgG RF have been unhelpful in patient management.

\section{Other autoantibodies}

Fluorescent ANAs in JCA usually have a homogeneous pattern on tissue substrates but $\mathrm{HEp}_{2}$ cell immunofluorescence of 131 JCA sera showed that nuclear staining was fine speckled in 65 and coarse 
speckled in $29 .{ }^{16}$ Antibodies to intracellular antigens (including Sm, RNP, PM-1, Scl-70, SS-A (Ro), and SS-B (La)) have been looked for in $20,{ }^{16} 35,{ }^{42}$ and $25^{43}$ patients with JCA. Only two children with polyarticular JCA without uveitis had anti-RNP, ${ }^{42}$ though a further three children with anti-Sm or antiRNP, or both, were reported among 150 patients with extractable nuclear antigens. ${ }^{44}$ Antibodies to rheumatoid arthritis nuclear antigen (RANA) were found in $8 \%$ of patients with JCA, all with active disease, but they did not correlate with the presence of RF. ${ }^{42}$ Anti-RANA may be frequently detected in normal people, however. ${ }^{45}$

Forty six serum samples from 35 patients with ANA positive JCA have been tested by counterimmunoelectrophoresis and 24 of them also by double immunodiffusion using as antigens either rabbit thymus powder, human spleen extract, $\mathrm{HEp}_{2}$ or HeLa cell extracts, and the results were again negative for Sm, Ro, La, PM-1, Scl-70, nuclear and ribosomal RNP, Jo-1, centromere and nucleolar antigens (Leak et al, unpublished data). Rosenberg et al found that two of 14 patients with ANA positive JCA had an antibody to a ribonuclease resistant component of extractable nuclear antigens (i.e., not ribonucleoprotein (RNP)) and one also had an antibody to transfer ribonucleic acid (RNA) by ELISA ${ }^{46}$ Although further ELISA studies may be useful, ${ }^{46}$ these more sensitive assays may measure a spectrum of antibodies whose clinical significance is uncertain. ${ }^{47}$

Homogeneous ANA patterns are often due to anti-deoxyribonucleic acid (anti-DNA) or antihistone antibodies. Cassidy et al reported a study of antibodies to native DNA by the Farr assay in 172 children with JCA, including 28 with uveitis, and $91 \%$ of the patients had active disease. ${ }^{48}$ All patients with JCA had less than $10 \%$ DNA binding with a mean of $2 \cdot 8 \%$, and Cassidy concluded that 'if properly controlled' antibodies to double stranded DNA (dsDNA) are absent in JCA. In several other studies of patients with JCA (Leak et al, unpublished data) ${ }^{7} 424649-51$ only occasional children have been found with low titre anti-dsDNA antibodies. ${ }^{46} 4950$

We have also screened 63 children with JCA for the common anti-DNA idiotype $16 / 6$ and found only one patient with systemic JCA with a raised value. ${ }^{52}$

Ten children have been reported who developed systemic lupus erythematosus (SLE) between 21/2 and 21 years after the onset of JCA ${ }^{53}$ At the time of diagnosis of SLE they had a mean DNA binding of $25 \%$, and retrospective study of stored serum samples showed that four patients had raised DNA binding before the clinical detection of SLE. In a child developing ANA positive arthritis after the age of 10, particularly in association with fever, or in a patient with JCA who develops persistent antibodies $\Rightarrow$ to dsDNA, the diagnosis of SLE should be carefully $\stackrel{?}{+}$ considered. ${ }^{54}$

Unlike antibodies to dsDNA, those binding single $\frac{\bar{D}}{\bar{N}}$ stranded DNA (ssDNA) are found in many dis- $\frac{\rho}{\vec{D}}$ orders and in healthy controls. ${ }^{55}$ We have found $\stackrel{\mathbb{D}}{\Omega}$ raised levels by ELISA in 12/26 ANA positive \& patients with median levels of IgG anti-ssDNA $\vec{\circ}$ antibodies (raised in eight patients) significantly higher than in other forms of JCA or controls ${ }^{52}$ and $\vec{\omega}$ not in association with active arthritis as reported by Haynes et al. ${ }^{17}$ Low titre anticardiolipin antibodies $\frac{0}{2}$ have been detected by radioimmunoassay in 10/34 patients with ANA positive JCA in association with $\dot{\omega}$ active arthritis and a poor outcome. ${ }^{52}$ The presence $\vec{\Delta}$ of anticardiolipin antibodies did not correlate with $\infty$ the presence of anti-ssDNA antibodies, and there 을 was no evidence of current infection or stigmata of the antiphospholipid syndrome. ${ }^{56}$ In systemic JCA and juvenile SLE anticardiolipin was often associated with active disease but also with infection. The significance of these findings needs to be evaluated in prospective studies.

Only occasional patients with JCA are positive for antihistone antibodies by the acid elution and reconstitution technique (Leak et al, unpublished data), ${ }^{174651}$ though this percentage may be higher in seropositive JCA as up to $24 \%$ of patients with rheumatoid arthritis have antihistone antibodies. ${ }^{3857}$

Preliminary observations with immunoblotting in $\mathrm{JCA}^{5859}$ suggest that antihistone antibodies may be responsible for the lines obtained in six out of nine patients with strongly positive homogeneous pattern ANAs $^{58}$ and in $24 / 50$ patients with pauciarticular JCA reported by Malleson et al. ${ }^{59}$ The commonest lines seen were a doublet at 33 kilodaltons, probably histone $\mathrm{Hl}$, but other lines at 40-49 kilodaltons were detected in 10 patients with JCA, none of whom had uveitis.

Numerous other immunological abnormalities have been identified in children with JCA, including $N$ antibodies to bovine type I and human type II collagen, ${ }^{17} 6061$ circulating immune complexes, ${ }^{62} 63 \stackrel{\sim}{\mathrm{N}}$ anti-T cell antibodies, ${ }^{64} 65$ and abnormalities in natural killer cell activity, ${ }^{66}$ the autologous mixed lymphocyte reaction, ${ }^{67}$ and the production of both 0

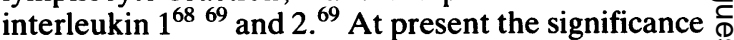
of these observations in the development of the disease is unclear.

\section{Conclusions}

It is likely that the ANAs in JCA bind to a number 0 of diverse nuclear antigens. Most well characterised 
autoantibodies are not found in JCA: the prevalence of some, such as anti-RNP, anti-DNA, and antiRANA, is low and they are usually found in association with active disease or polyarthritis, or both. The striking association of ANAs with chronic iridocyclitis suggests an aetiopathogenic role and gives impetus to the search for the intracellular antigen involved. The ANAs in seropositive juvenile rheumatoid arthritis, probably of different immunospecificity, have been little studied and although the role of IgM RF in erosive polyarthritis is recognised, as in adult RA further characterisation of the relation between ANAs and RF may help in understanding the aetiology of the disease. ${ }^{38}$ It is important that all studies use well defined subgroups of patients to clarify some of the unresolved questions about autoantibodies in JCA.

\section{References}

1 Allen R C, Ansell B M. Juvenile chronic arthritis-clinical subgroups with particular relationship to adult patterns of disease. Postgrad Med J 1986; 62: 821-6.

2 Ansell B M, Albert E. Joint report; juvenile chronic arthritis. Pauciarticular type. In: Albert E, Baum M P, Mayr W R, eds. Histocompatibility testing. Berlin: Springer, 1984: 368-74.

3 Martini A. Immunological aspects of juvenile chronic arthritis. In: Andrianakos A, Kappou L, Mavrikakis M, Moutsopoulos $\mathrm{H}$, eds. Eurorheumatology proceedings. Athens, Greece: Tagas and Son Press, 1987: 62-5.

4 Clemens L E, Albert E, Ansell B M. HLA studies in IgM rheumatoid factor positive arthritis of childhood. Ann Rheum Dis 1983; 42: 431-4.

5 Bianco N E. Panush R S. Stillman J S. Schur P H. Immunologic studies in juvenile rheumatoid arthritis. Arthritis Rheum 1971; 14: $685-96$

6 Cassidy J T, Levinson J E, Bass J C, et al. A study of classification criteria for a diagnosis of juvenile rheumatoid arthritis. Arthritis Rheum 1986; 29: 274-81.

7 Schaller J G, Johnson G D, Holborow E J, Ansell B M. Smiley W K. The association of antinuclear antibodies with the chronic iridocyclitis of juvenile rheumatoid arthritis (Still's disease). Arthritis Rheum 1974; 17: 409-16.

8 Beutner E H. Krasny S A. Chorzelski T P. Rodnan G. Jablonska S, Kumar V. Evaluation of methods for detection of anticentromere antibodies and other antinuclear antibodies. $J$ Am Acad Dermatol 1985; 12: 289-95.

9 Wiik A. Antinuclear factors in sera from healthy blood donors. Acta Pathologica et Microbiologica Scandinavica. Section C, Immunology, 1976; 84: 215-20.

10 Permin H, Horbov S, Wiik A, Knudsen J V. Antinuclear antibodics in juvenile chronic arthritis. Acta Paediatr Scand 1978; 67: 181-5.

11 Ravelli A, De Benedetti F, Viola S, Sambugars R, Leone M, Martini A. Incidence of autoantibodies in healthy children of different ages [Abstract]. Proceedings of the XVII Congress of the Union of Middle-Eastern and Mediterranean Paediatric Societies, Palermo. 1987: 59.

12 Chudwin D S, Ammann A J, Cowan M J, Wara D W. Significance of a positive antinuclear antibody test in a pediatric population. Am J Dis Child 1983; 137: 1103-6.

13 Ammann A J, Hong R. Selective IgA deficiency: presentation of 30 cases and a review of the literature. Medicine (Baltimore) 1971; 50: 223-6.

14 Cassidy J T, Petty R E, Sullivan D B. Occurrence of selective
IgA deficiency in children with juvenile rheumatoid arthritis. Arthritis Rheum 1977: 20: 181-3.

15 Kaplan M E, Tan E M. Antinuclear antibodies in infectious mononucleosis. Lancet 1968; i: 561-3.

16 Osborn T G, Patel N J, Moore T L, Zuckner J. Use of the HEp 2 cell substrate in the detection of antinuclear antibodies in juvenile rheumatoid arthritis. Arthritis Rheum 1984; 27: 1286-9.

17 Haynes D C, Gershwin M E, Robbins D L. Miller J J, Cosca D. Autoantibody profile in juvenile arthritis. $J$ Rheumatol 1986; 13: $358-63$.

18 Petty R E, Cassidy J T, Sullivan D B. Clinical correlates of antinuclear antibodies in juvenile rheumatoid arthritis. J Pediatr 1973; 83: 386-9.

19 Hoyeraal H M. Granulocyte reactive antinuclear factors in juvenile rheumatoid arthritis. Scand J Rheumatol 1976; 5: 84-90.

20 Egeskjold E M, Johansen A, Permin H, Hoyeraal H M, Sorensen $T$. The significance of antinuclear antibodies in juvenile rheumatoid arthritis associated with chronic bilateral iridocyclitis. Acta Paediatr Scand 1982; 71: 615-20.

21 Calin A, Calin H J. Oligoarthropathy with chronic iridocyclitis-A disease only of childhood? J Rheumatol 1982; 9: 105-6.

22 Hall P J, Burman S J, Laurent M R, et al. Genetic susceptibility to early onset pauciarticular juvenile chronic arthritis: a study of HLA and complement markers in 158 British patients. Ann Rheum Dis 1986; 45: 464-74.

23 Glass D, Litvin K, Wallace L, et al. Early-onset pauciarticular juvenile rheumatoid arthritis associated with human leukocyte antigen-DRw5, iritis and antinuclear antibody. J Clin Invest 1980; 66: 426-9.

24 Chylack L T. The ocular manifestations of juvenile rheumatoid arthritis. Arthritis Rheum 1977; 20: 217-23.

25 Fink C W, Ansell B M, Wood P H N. Juvenile arthritis in England: a long term follow up [Abstract]. Arthritis Rheum 1980; 23: 673 .

26 Hollister $J$ R. What is the risk of chronic iridocyclitis in pauciarticular juvenile rheumatoid arthritis? [Abstract]. $J$ Rheumatol 1986; 13: 977.

27 Kanski J J. Anterior uveitis in juvenile rheumatoid arthritis. Arch Ophthalmol 1977; 95: 1794-7.

28 Key S N. Kimura S J. Iridocyclitis associated with juvenile rheumatoid arthritis. Am J Ophthalmol 1975; 80: 425-9.

29 Leak A M, Ansell B M. The relationship between ocular and articular disease activity in juvenile rheumatoid arthritis complicated by chronic anterior uveitis. Arthritis Rheum (in press)

30 Rahi A H S. Kanski J J, Fielder A. Immunoglobulins and antinuclear antibodies in aqueous humour from patients with juvenile 'rheumatoid' arthritis (Still's disease). Trans Ophthalmol Soc UK 1977; 97: 217-22.

31 Petty R E, Hunt D W G, Rollins D F, Schroeder M L, Puterman M L. Immunity to soluble retinal antigen in patients with uveitis accompanying juvenile rheumatoid arthritis. Arthritis Rheum 1987; 30: 287-93.

32 Petty R E. Current knowledge of the etiology and pathogenesis of chronic uveitis accompanying juvenile rheumatoid arthritis. Rheumatic Diseases Clinics of North America 1987; 13: 19-36.

33 Leak A M, Burman S J, Ansell B M. Antinuclear antibody studies in juvenile chronic arthritis. Arch Dis Child 1986; 61: 168-72.

34 Schaller J G. Juvenile rheumatoid arthritis. Pediatr Ann 1982; 11: $375-82$.

35 Wernick R, LoSpalluto J J, Fink C W, Ziff M. Serum IgG and IgM rheumatoid factors by solid phase radioimmunoassay. Arthritis Rheum 1981; 24: 1501-11.

36 Egeskjold Limschou E-M. Autoantibodies in juvenile connective tissue disorders. Dan Med Bull 1986; 5: 248-56.

37 Torrigiani G, Ansell B M. Chown E A, Roitt I M. Raised IgG antiglobulin factors in Still's disease. Ann Rheum Dis 1969; 28: 424-7. 
38 Aitcheson C T, Peebles C, Joslin F, Tan E M. Characteristics of antinuclear antibodies in rheumatoid arthritis. Arthritis Rheum 1980; 23: 528-38.

39 Moore T L, Dorner R W, Weiss T D, Baldassare A R, Zuckner J. Hidden 19S IgM rheumatoid factor in juvenile rheumatoid arthritis. Pediatr Res 1980; 14: 1135-8.

40 Moore T L, Dorner R W, Sheridan P W, et al. Longitudinal study of the presence of hidden $19 \mathrm{~S}$ rheumatoid factor in juvenile rheumatoid arthritis. $J$ Rheumatol 1982; 9: 599-602.

41 Balogh Z, Meretev K, Falus A, Bozsoky S. Serologic abnormalities in juvenile chronic arthritis: a review of 46 cases. Ann Rheum Dis 1980; 39: 129-34.

42 Alspaugh M A, Miller J J. A study of specificities of antinuclear antibodies in juvenile rheumatoid arthritis. J Pediatr 1977; 90: 391-5.

43 Siamopoulos-Mavrides A D, Mavrides A K. Antinuclear antibodies in Greek juvenile rheumatoid arthritis. Clin Exp Rheumatol 1984; 3: 362-3.

44 Munves E F, Schur P H. Antibodies to Sm and RNP. Prognosticators of disease involvement. Arthritis Rheum 1983; 26: 848-53.

45 Catalano M A, Carson D A, Stastny P, Freer S, Vaughan J H. Correlation between anti-RANA and anti-EBNA titres in normal subjects with and without HLA-DRw4. Arthritis Rheum 1980; 23: 1049-52.

46 Rosenberg A M, Cordiero D M, Knause R P. Studies on the specificity of antinuclear antibodies (ANA) in juvenile rheumatoid arthritis [Abstract]. Arthritis Rheum 1983; 26: S57.

47 Walport M. The identification of autoantigens, autoantibodies and their idiotypes. Br J Rheumatol 1987; 26: 161-3.

48 Cassidy J T, Walker S E, Soderstrom S J, Petty R E, Sullivan D B. Diagnostic significance of antibody to native DNA in children with juvenile chronic arthritis. J Pediatr 1978; 93: 416-20.

49 Rudnicki R D, Ruderman M, Scull E, Goldenberg A, Rothfield $\mathrm{N}$. Clinical features and serological abnormalities in juvenile rheumatoid arthritis. Arthritis Rheum 1974; 17: 1007-15.

50 Permin H, Halberg P, Christiansen E. Antibodies against dsDNA in patients with connective tissue disorders. Acta Med Scand 1978; 203: 61-5.

51 Saulsbury F T. Antinuclear antibody specificity in juvenile chronic arthritis. Clin Res 1985; 33: 512A

52 Leak A M, Colaco C B, Isenberg D A, Dudeney C, Ansell B M. Anticardiolipin and anti-ssDNA antibodies in antinuclear antibody positive juvenile chronic arthritis and other childhood onset rheumatic diseases [Abstract]. Clin Exp Rheumatol 1987; 5 (suppl 2): 18

53 Ragsdale C G, Petty R E, Cassidy J T, Sullivan D B. The clinical progression of apparent juvenile rheumatoid arthritis to systemic lupus erythematosus. $J$ Rheumatol 1980; 7: 50-5.

54 Martini A, Ravelli A, Viola S, Burgio R G. Systemic lupus erythematosus with Jacoud's arthropathy mimicking juvenile rheumatoid arthritis. Arthritis Rheum 1987; 30: 1062-4.
55 Bell C, Takal N, Schur P H. Antibodies to DNA in patients with rheumatoid arthritis and juvenile chronic arthritis Arthritis Rheum 1975; 18: 535-40.

56 Hughes G R V, Harris N N, Gharavi A E. The anticardiolipin syndrome. J Rheumatol 1986; 13: 486-9.

57 Garcia-de la Torre I, Miranda-Mendez L. Studies of antinuclear antibodies in rheumatoid arthritis. J Rheumatol 1982; 9: 603-6.

58 Brunet C, Craft J, Nakamura M, Pachman L, Athreya B, Hardin $\mathrm{J}$. Identification of nuclear antigens bound by sera from patients with juvenile rheumatoid arthritis [Abstract]. Arthritis Rheum 1986; 29: S67.

59 Malleson P N, Fung M, Petty R E. Antigenic heterogeneity of antinuclear antibodies in juvenile rheumatoid arthritis determined by immunoblotting [Abstract]. Arthritis Rheum 1987; 30: S126.

60 Steffen C, Sanger L, Menzel J. Demonstration of antibodies to denatured type I and type II collagen in juvenile rheumatoid arthritis, Still's syndrome and controls by ${ }^{14} \mathrm{C}$ collagen radioimmunoassay. Scand J Rheumatol 1980; 9: 69-76.

61 Rosenberg A M, Hunt D W C, Petty R E. Antibodies to native and denatured type II collagen in children with rheumatic diseases. J Rheumatol 1984; 11: 425-31.

62 Latzka U, Menzel E J. Granninger W, Steffen C. Immune complexes in juvenile chronic arthritis. Rheumatol Int 1984; 4: 45-8.

63 Rossen R D, Brewer E J, Person D A, Templeton J W, Lidsky M D. Circulating immune complexes and antinuclear antibodics in juvenile rheumatoid arthritis. Arthritis Rheum 1977; 20: 1485-90.

64 Barron K S, Lewis D E, Brewer E J, Marcus D M, Shearer W T. Cytotoxic anti-T cell antibodies in children with juvenile rheumatoid arthritis. Arthritis Rheum 1984; 27: 1272-80.

65 Borel Y, Morimoto C, Cairns L, et al. Anti-T cell antibody in juvenile rheumatoid arthritis. $J$ Rheumatol 1984; 11: 56-61.

66 Dobloug J H, Førre O, Kvien T K, Egeland T, Degré $M$. Natural killer cell activity of peripheral blood, synovial fluid, and synovial tissue lymphocytes from patients with rheumatoid arthritis and juvenile rheumatoid arthritis. Ann Rheum Dis 1982; 41: 490-4.

67 Førre O, Egeland T, Dobloug J H, Kvien T K, Natvig J B Autologous mixed lymphocyte reactions in patients with rheumatoid arthritis and juvenile arthritis: both non-T cells and in-vivo-activated T cells can act as stimulator cells. Scand $J$ Immunol 1982; 16: 173-9.

68 Prieur A-M, Kaufmann M-T, Griscelli C, et al. Interleukin I and interleukin $I$ inhibitor activity in the sera and urine of children with systemic juvenile chronic arthritis. In: Andrianakos A, Kappou L, Mavrikakis M, Moutsopoulos H, eds. Eurorheumatology proceedings. Athens, Greece: Tagas and Son Press, 1987: 66-9.

69 Martini A, Ravelli A, Notarangelo L D, et al. Enhanced interleukin I and depressed interleukin II production in juvenile arthritis. $J$ Rheumatol 1986; 13: 598-603. 